Note

\title{
Endoplasmic Reticulum (ER) Stress-Suppressive Compounds from Scrap Cultivation Beds of the Mushroom Hericium erinaceum
}

\author{
Keiko Ueda, ${ }^{1}$ Shinya Kodani, ${ }^{1,2}$ Masakazu Kubo, ${ }^{3}$ Kazuhiko Masuno, ${ }^{4}$ Atsushi Sekiya, ${ }^{5}$ \\ Kaoru NAGAI, ${ }^{6, \dagger}$ and Hirokazu KawAGishi ${ }^{1,2, \uparrow}$ \\ ${ }^{1}$ Graduate School of Science and Technology, Shizuoka University, 836 Ohya, Suruga-ku, Shizuoka 422-8529, Japan \\ ${ }^{2}$ Department of Applied Biological Chemistry, Faculty of Agriculture, Shizuoka University, \\ 836 Ohya, Suruga-ku, Shizuoka 422-8529, Japan \\ ${ }^{3}$ Kubo Industry Co., Ltd., 580 Ikigaya, Oaza, Chikuma, Nagano 387-0003, Japan \\ ${ }^{4}$ Nagano Prefecture General Forest Research Center, 5739 Kataoka, Shiojiri, Nagano 399-0711, Japan \\ ${ }^{5}$ Forestry and Forest Products Research Institute, 1 Matsunosato, Tsukuba, Ibaraki 305-8687, Japan \\ ${ }^{6}$ Department of Epigenetic Medicine, Interdisciplinary Graduate School of Medicine and Engineering, \\ University of Yamanashi, Yamanashi 409-3898, Japan
}

Received April 16, 2009; Accepted May 8, 2009; Online Publication, August 7, 2009

[doi:10.1271/bbb.90279]

Four compounds were isolated from scrap cultivation beds of the mushroom, Hericium erinaceum. Compounds 1-4 were identified as methyl 4-hydroxy-3-(3-methylbutanoyl) benzoate, 2-chloro-1,3-dimethoxy-5-methylbenzene, methyl 4-chloro-3,5-dimethoxybenzoate, and 4chloro-3,5-dimethoxybenzaldehyde by an interpretation of the NMR and MS data, respectively. This is the first reported isolation of 1 from a natural source. All the compounds showed protective activity against endoplasmic reticulum stress-dependent cell death.

Key words: Hericium erinaceum; mushroom; scrap cultivation bed; structural determination; endoplasmic reticulum stress-suppressive compound

Endoplasmic reticulum (ER) stress induces an apoptotic pathway in cells with signaling between ER and mitochondria. By triggering apoptosis in neural cells, stress is a major cause of such degenerative disorders as Alzheimer disease. ${ }^{1,2)}$ The demand for new protective substances against the ER stress-dependent cell death prompted us to screen the protective activity of mushroom extracts. We have recently found dilinoleoylphosphatidylethanolamine and hericenone-related compounds as protective principles from the mushroom, Hericium erinaceum. ${ }^{3,4)}$ In the course of further extensive screening, we found protective activity in an extract from the scrap cultivation bed of $H$. erinaceum. The cultivation bed is usually discarded by the mushroom growers after harvesting the fruiting bodies. Another purpose of this study is efficient use of scrap cultivation beds. We describe here the isolation, structural identification, and biological activity of compounds 1-4 from a scrap cultivation bed of the mushroom, $H$. erinaceum.

The scrap cultivation bed of $H$. erinaceum was successively extracted with EtOH and acetone. The combined extract was subjected to two-layer-partitioning between $\mathrm{H}_{2} \mathrm{O}$ and $n$-hexane. The hexane extract was

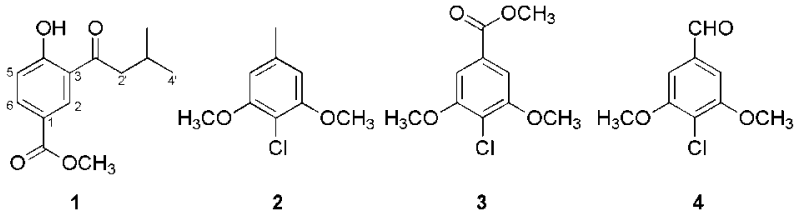

separated by silica gel column chromatography and subsequent reversed-phase HPLC to afford compounds 1-4.

Compound 1 was purified as red crystals. Its molecular formula was determined as $\mathrm{C}_{13} \mathrm{H}_{16} \mathrm{O}_{4}$ by HRESIMS, $m / z \quad 253.09272 \quad[\mathrm{M}-\mathrm{H}]^{+}$(calcd. for $\mathrm{C}_{13} \mathrm{H}_{15} \mathrm{O}_{4}$, 235.09703). The complete assignment of all the protons and carbons was accomplished by DEPT, HMQC, COSY, and HMBC experiments as follows: ${ }^{1} \mathrm{H}-\mathrm{NMR}$ (in $\left.\mathrm{CD}_{3} \mathrm{OD}\right) \delta: 8.53(1 \mathrm{H}, \mathrm{d}, J=2.1 \mathrm{~Hz}, \mathrm{H}-2), 8.09(1 \mathrm{H}$, $\mathrm{dd}, J=8.9,2.1 \mathrm{~Hz}, \mathrm{H}-6), 7.00(1 \mathrm{H}, \mathrm{d}, J=8.9 \mathrm{~Hz}, \mathrm{H}-5)$, $3.90\left(3 \mathrm{H}, \mathrm{s},-\mathrm{OCH}_{3}\right), 2.97\left(2 \mathrm{H}, \mathrm{d}, J=6.7, \mathrm{H}-2^{\prime}\right), 2.27$ $\left(1 \mathrm{H}, \mathrm{m}, \mathrm{H}-3^{\prime}\right), 1.02\left(6 \mathrm{H}, \mathrm{d}, J=6.4 \mathrm{~Hz}, \mathrm{H}-4^{\prime}, 3^{\prime}-\mathrm{CH}_{3}\right)$ : ${ }^{13} \mathrm{C}-\mathrm{NMR} \delta: 207.9\left(\mathrm{C}-1^{\prime}\right), 167.4$ (-COO-), 167.1 (C-4), 137.8 (C-6), 133.8 (C-2), 122.2 (C-1), 120.6 (C-3), $119.5(\mathrm{C}-5), 52.7\left(-\mathrm{OCH}_{3}\right), 48.1\left(\mathrm{C}-2^{\prime}\right), 26.4\left(\mathrm{C}-3^{\prime}\right)$, $22.9\left(\mathrm{C}-4^{\prime}, 3^{\prime}-\mathrm{CH}_{3}\right)$. The DEPT experiment indicated the presence of 3 methyls, a methylene, 4 methines, and 5 quaternary carbons. The COSY and HMBC correlations are illustrated in Fig. 1. Compound $\mathbf{1}$ had a 1,2,4trisubstituted phenyl group in the molecule; $\delta 8.53$ (d, $J=2.1 \mathrm{~Hz}, \mathrm{H}-2), \delta 8.09$ (dd, $J=8.9,2.1 \mathrm{~Hz}, \mathrm{H}-6)$, and $\delta 7.00(\mathrm{~d}, J=8.9 \mathrm{~Hz}, \mathrm{H}-5)$. The moiety of $3^{\prime}-$ methylbutanoyl was assigned by the COSY correlations (H-2' $\left./ \mathrm{H}-3^{\prime}, \mathrm{H}-3^{\prime} / \mathrm{H}-4^{\prime}, \mathrm{H}-3^{\prime} / 3^{\prime}-\mathrm{Me}\right)$ and HMBC correlations $\left(\mathrm{H}-2^{\prime} / \mathrm{C}-1^{\prime}, \mathrm{H}-2^{\prime} / \mathrm{C}-3^{\prime}, \mathrm{H}-2^{\prime} / \mathrm{C}-4^{\prime}, \mathrm{H}-2^{\prime} / 3^{\prime}-\mathrm{Me}\right.$, $\mathrm{H}-3^{\prime} / \mathrm{C}-2^{\prime}, \quad \mathrm{H}-3^{\prime} / \mathrm{C}-4^{\prime}, \quad \mathrm{H}-3^{\prime} / 3^{\prime}-\mathrm{Me}, \mathrm{H}-4^{\prime} / \mathrm{C}-2^{\prime}, \quad \mathrm{H}-4^{\prime} /$ $\mathrm{C}-3^{\prime}, \quad \mathrm{H}-4^{\prime} / 3^{\prime}-\mathrm{Me}, \quad 3^{\prime}-\mathrm{Me} / \mathrm{C}-2^{\prime}, \quad 3^{\prime}-\mathrm{Me} / \mathrm{C}-3^{\prime}, \quad 3^{\prime}-\mathrm{Me} /$ $\left.\mathrm{C}-4^{\prime}\right)$. The COSY correlation indicated connection between $\mathrm{H}-5$ and H-6. The connection between the methoxycarbonyl and phenyl was indicated by HMBC correlations from $\mathrm{H}-2$ and $\mathrm{H}-6$ to the carbonyl. The

To whom correspondence should be addressed. Hirokazu KawAGISHI, Tel/Fax: +81-54-238-4885; E-mail: achkawa@agr.shizuoka.ac.jp; Kaoru NAGAI, Fax: +81-55-273-9561; E-mail: kaoru@yamanashi.ac.jp 
connection between the $3^{\prime}$-methylbutanoyl and phenyl was determined by the HMBC correlation from $\mathrm{H}-2^{\prime}$ to $\mathrm{C}-3$. As a result, the structure of $\mathbf{1}$ was identified as methyl 4-hydroxy-3-(3-methylbutanoyl)benzoate (Fig. 1). This is the first report of compound $\mathbf{1}$ being isolated from a natural source. ${ }^{5)}$

Combined analyses of the NMR and MS data enabled compounds 2-4 to be identified as shown. These compounds have previously been isolated from the mycelia of $H$. erinaceum. ${ }^{6,7)}$

Compounds 1-4 were subjected to a protection assay against ER stress-dependent cell death. ${ }^{3)}$ The ER stress was induced by adding tunicamycin or thapsigargin to the culture medium of Neuro2a cells in the presence or absence of these compounds. Tunicamycin is an inhibitor of $\mathrm{N}$-glycosylation to glycoproteins in ER
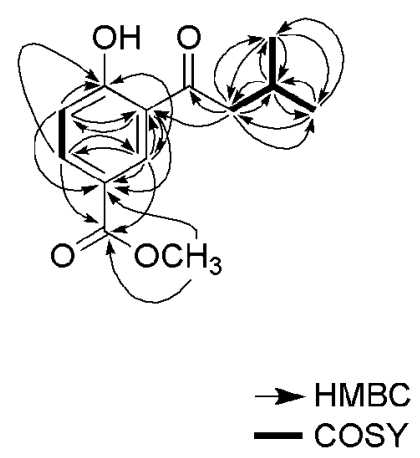

Fig. 1. 2D NMR Correlations for $\mathbf{1}$.
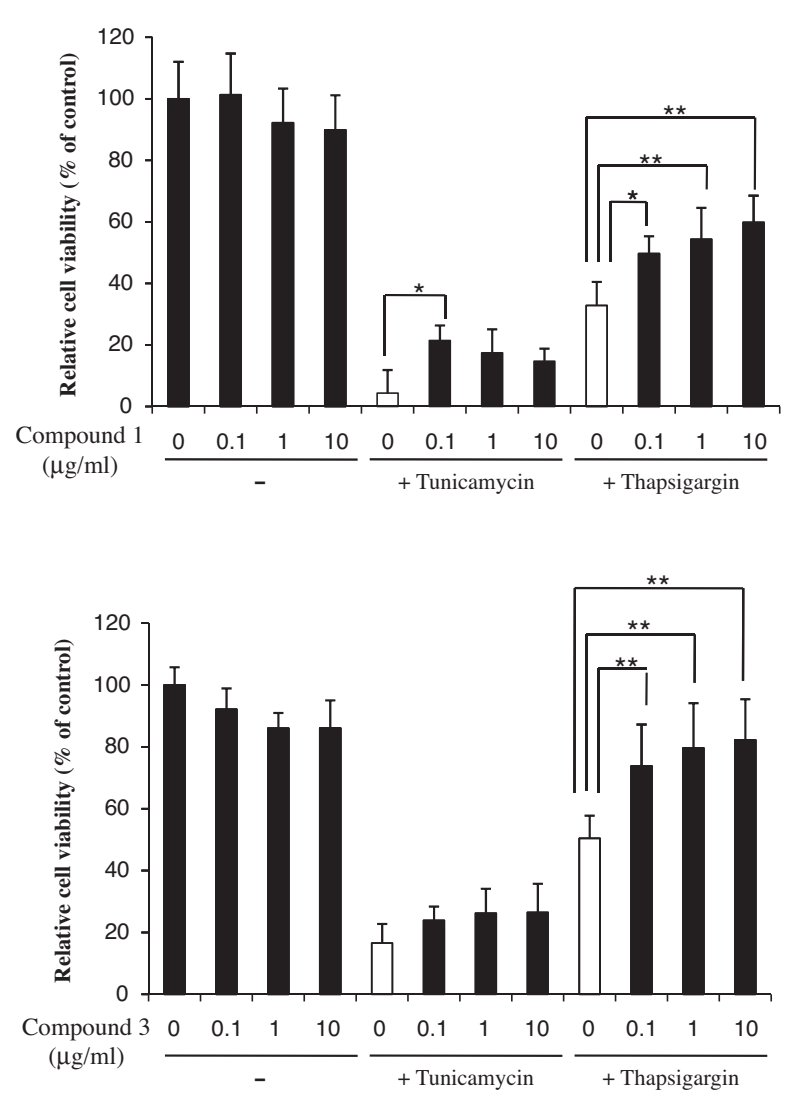

and causes protein-misfolding in ER. Thapsigargin is an ER $\mathrm{Ca}^{2+}$-ATPase inhibitor that causes $\mathrm{Ca}^{2+}$ depletion in ER. Compounds 1, 2, and 4 showed significant protective activity against the ER stress caused by tunicamycin and by thapsigargin (Fig. 2). Compound $\mathbf{3}$ exhibited similar protective activity against the ER stress induced by thapsigargin, although it showed comparatively weak activity in the test using tunicamycin.

This result indicates that the scrap cultivation bed of the mushroom can be a useful resource of biologically active compounds.

Fungal strain and culture conditions. The strain of H. erinaceum was isolated from a fruiting body collected in Nagano Prefecture. Voucher material has been deposited in the research laboratory of Kubo Industry, Nagano Prefecture, Japan. The culture medium (520 g) was prepared by mixing soybean peel $(35 \mathrm{~g})$, corn powder $(36 \mathrm{~g})$, dried tofu refuse $(10 \mathrm{~g})$, activated carbon ( $2 \mathrm{~g}$ ) and Japanese beech sawdust and adjusted to $62 \%$ moisture by using an FD600 moisture meter (Kett Electric Laboratory Co., Japan). The medium was packed in polypropylene bottles (520 g/bottle) and autoclaved. The pre-cultured mycelium was inoculated into the bottle. After cultivating under $21^{\circ} \mathrm{C}$ and $65 \%$ humidity in the dark for 2 weeks, fruiting body induction and further cultivation were done under $15^{\circ} \mathrm{C}$ and $68 \%$ humidity in the light for $4 \mathrm{~d}$ in an incubator (USC3004, Mikuni Co., Japan). The humidity was controlled by a humidity adjuster (H3CR, Omron Co., Japan). After harvesting the fruiting bodies, the scrap cultivation bed was collected for extraction.
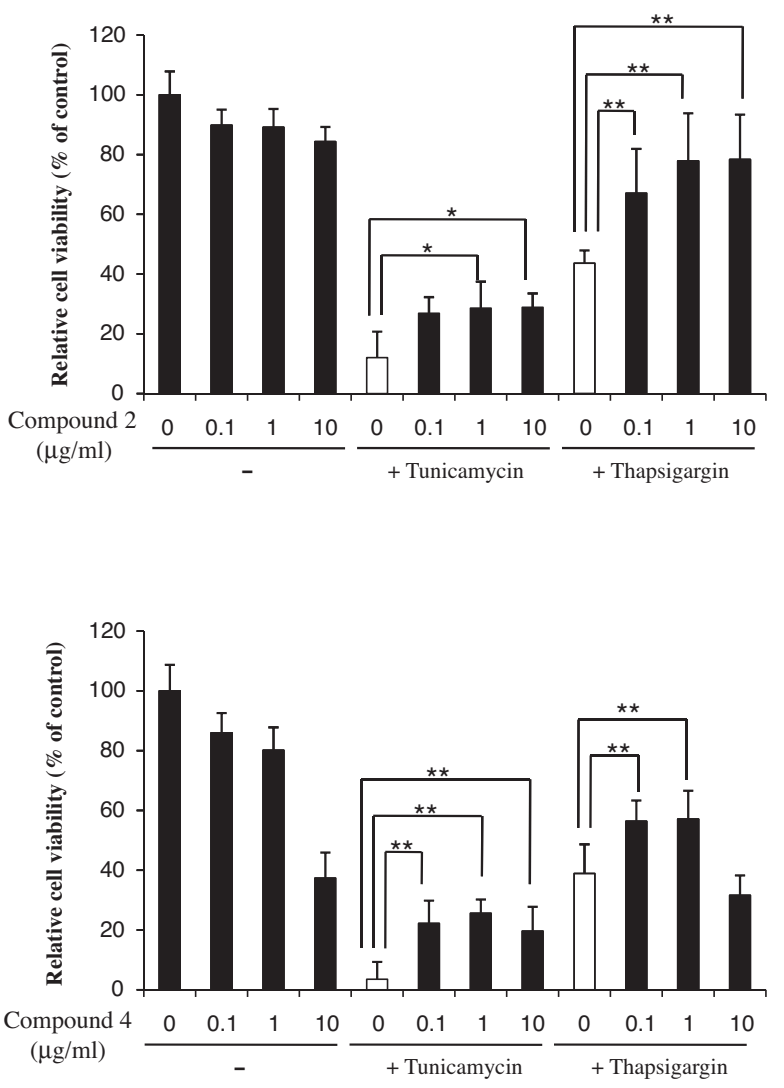

Fig. 2. Protective Activity of 1-4 against ER Stress-Dependent Cell Death.

The cell viability was analyzed by an MTT assay, and each value is presented as the mean \pm SD of the relative percentage of surviving cells compared with the untreated cells $(\mathrm{n}=8) .{ }^{*} p<0.05,{ }^{* *} p<0.01$, non-paired $t$-test. 
General experiments. ${ }^{1} \mathrm{H}-\mathrm{NMR}$ spectra were recorded by a Jeol lambda-500 spectrometer at $500 \mathrm{MHz}$, while ${ }^{13} \mathrm{C}-\mathrm{NMR}$ spectra were recorded by the same instrument at $125 \mathrm{MHz}$. The HRESIMS data were measured by a JMS-T100LC mass spectrometer. HPLC separation was performed with a Jasco Gulliver system. Silica gel plates (Merck $\mathrm{F}_{254}$ ) and silica gel 60N (Merck 100-200 mesh) were respectively used for analytical TLC and flash column chromatography.

Extraction and isolation. The scrap cultivation bed for H. erinaceum $(2.7 \mathrm{~kg})$ was successively extracted with $85 \%$ ethanol (14 liters), acetone (14 liters), and hexane (2 liters-three times). The hexane faction was evaporated under reduced pressure to an aqueous residue. The hexane-soluble part $(9.9 \mathrm{~g})$ was fractionated by silica gel flash column chromatography, eluting with a solvent of $n$-hexane/acetone in various ratios $(9: 1,7: 3,5: 5$ and 1:9), acetone and $\mathrm{MeOH}$ to obtain fourteen fractions (fractions 1 to 14). Fraction 4 ( $n$-hexane/acetone $=$ 95:5, $432.2 \mathrm{mg}$ ) was separated by ODS Sep-Pak with elution by $\mathrm{MeOH}$. The non-adsorbed fraction $(56.4 \mathrm{mg})$ was further separated by reversed-phase HPLC in a C30 column (Wako Pak navi), with elution by $\mathrm{MeOH}$, to afford compound 1 (16.7 mg). Fraction 5 ( $n$-hexane/ acetone 95:5-9:1, 4.0 g) was separated by silica gel flash column chromatography, eluting with $n$-hexane/acetone (9:1, 7:3 and 5:5), acetone and $\mathrm{MeOH}$ to obtain thirteen fractions (fractions 5-1 to -13). Fraction 5-3 ( $n$-hexane/ acetone $=9: 1)$ was compound $2(908.4 \mathrm{mg})$. Fraction 5-5 ( $n$-hexane/acetone 9:1-7:3, 83.6 mg) was separated by ODS Sep-Pak, with elution by $80 \% \mathrm{MeOH}$. The nonadsorbed fraction $(28.9 \mathrm{mg})$ was further separated by reversed-phase HPLC in a C30 column (Develosil C30 UG-5), with elution by $80 \% \mathrm{MeOH}$, to afford compound $3(8.4 \mathrm{mg}$ ). Fraction 6 (hexane/acetone $=9: 1,976.8$ $\mathrm{mg}$ ) was separated by silica gel flash column chromatography, eluting with $n$-hexane/acetone $(95: 5,9: 1,7: 3$, 5:5 and 2:8), acetone and $\mathrm{MeOH}$ to obtain nine fractions (fractions 6-1 to -9). Fraction 6-4 ( $n$-hexane/acetone $7: 3,154.9 \mathrm{mg}$ ) was separated by silica Sep-Pak with elution by $\mathrm{CHCl}_{3}$. The non-adsorbed fraction $(154.0 \mathrm{mg})$ was further separated by HPLC in a silica gel column (Develosil 60), with elution by $\mathrm{CHCl}_{3}$, to obtain seventeen fractions (fractions 6-4-1 to -17). Fraction 6-4-4 was separated by ODS Sep-Pak with elution by $90 \% \mathrm{MeOH}$. The non-adsorbed fraction (4.2 mg) was further separated by reversed-phase HPLC, using a C30 column (Develosil C30 UG-5) and elution by $90 \%$ $\mathrm{MeOH}$, to afford compound 4 (3.0 mg).

Cell viability. Cell viability was evaluated by a 3-(4,5dimethyl-2-thiazolyl) 2,5-diphenyl-2 $\mathrm{H}$-tetrazolium bromide (MTT) assay. The cell protection assay on ER stress by the MTT assay was performed on neuro2a cells that were cultured in 96-well plates at a cell density of 5000 cells/well. After one day of cultivation, the cells were cultured in D-MEM without FBS, and $0.5 \mu \mathrm{g} / \mathrm{ml}$ of tunicamycin (or thapsigargin) and varying concentrations of compounds 1-4 were each applied to the medium. The cells were incubated for $24 \mathrm{~h}$, and then the viability was measured by the MTT assay, as described previously. ${ }^{8)}$ Briefly, $0.25 \mathrm{mg} / \mathrm{ml}$ of MTT in D-MEM without FBS was added to the cells which were incubated for $2 \mathrm{~h}$. Incubation was terminated by adding $20 \%$ SDS (v/w) and 50\% dimethylformamide (v/v) in water. The absorbance at $570 \mathrm{~nm}$ of the reaction mixture was measured by a microplate reader (Molecular Devices, USA).

\section{References}

1) Nakagawa T, Zhu H, Morishima N, Li E, Xu J, Yankner BA, and Yuan J, Nature, 403, 98-103 (2000).

2) Nakagawa T and Yuan J, J. Cell Biol., 150, 887-894 (2000).

3) Nagai K, Chiba A, Nishino T, Kubota T, and Kawagishi H, J. Nutr. Biochem., 17, 525-530 (2006).

4) Ueda K, Tsujimori M, Kodani S, Chiba A, Kubo M, Masuno K, Sekiya A, Nagai K, and Kawagishi H, Bioorg. Med. Chem., 16, 9467-9470 (2008).

5) Detsi A, Roussis V, Tsotinis A, Roussakis C, and Calogeropoulou T, Synlett, 20, 3131-3135 (2005).

6) Qian FG, Xu GY, Du SJ, and Li MH, Yaoxue Xuebao, 25, 522525 (1990).

7) Okamoto K, Shimada A, Shirai R, Sakamoto H, Yoshida S, Ojima F, Ishiguro Y, Sakai T, and Kawagishi H, Phytochemistry, 34, 1445-1446 (1993).

8) Liu Y, Peterson DA, Kimura H, and Schubert D, J. Neurochem., 69, 581-593 (1997). 